\title{
MOTIVATION AS ONE OF THE CONSTITUENT COMPONENTS OF THE MODEL OF THE SYSTEM OF MEDICAL AND PSYCHOLOGICAL SUPPORT FOR THE PROCESS OF ADAPTATION OF MEDICAL COLLEGE STUDENTS TO WORK IN PRIMARY POSITIONS
}

DOI: 10.36740/WLek202006116

\author{
Olena V. Gryshnjaeva ${ }^{1,2}$, Oleksandr A. Melnychenko ${ }^{1}$, Galyna V. Yeryomenko ${ }^{1}$, Victoria V. Grigoruk ${ }^{1}$, \\ Vita V. Antsupova ${ }^{3}$, Yana A. Vanina ${ }^{4}$ \\ ${ }^{1}$ KHARKIV NATIONAL MEDICAL UNIVERSITY, KHARKIV, UKRAINE \\ 2KHARKIV ACADEMY OF POSTGRADUATE EDUCATION, KHARKIV, UKRAINE \\ 3BOHOMOLETS NATIONALITY MEDICAL UNIVERSITY, KYIV, UKRAINE \\ ${ }^{4}$ KHARKIV REGIONAL INSTITUTE OF STATE ADMINISTRATION NATIONAL ACADEMY OF STATE ADMINISTRATION AT PRESIDENT OF UKRAINE, KHARKIV, \\ UKRAINE
}

\begin{abstract}
The aim: Based on previous studies, develop medical and psychological recommendations to increase the motivation for the work of nurses and medical assistants. Materials and methods: During 2015-2018Students of the Kharkov Regional Medical College (100 experimental people and 100 control groups) studied the types of motivation of medical personnel to work in key positions. The article analyzes the relationship between motivation and the individual - typological characteristics of the person using the psychodiagnostic methodology of the individually - typological questionnaire L.N. Sobchik and author's profile A.V. Grishnyaeva.

Results: After analyzing the above data, we can say that a combination of motivation or its absence with certain individual and typological characteristics of individuals leads to different results of adaptation to the primary positions of future medical workers. The imbalance of individual-personality structures and motivation leads to an accentuation of character, which contributes to maladaptation and professional burnout.

Conditions: Given the connection between motivation and individual - typological characteristics of the personality, it is possible to make the correct personnel distribution and prevent the professional burnout of employees.
\end{abstract}

KEY WORDS: material and non material motivation, students, adaptation, individually-typological features, medical workers

Wiad Lek. 2020;73(6):1164-1168

\section{INTRODUCTION}

During the reform of the healthcare system in Ukraine, first of all, attention should be paid to the education and training of medical personnel. That is, we can say that the reform must be read from the educational process, which includes a multi-factor approach: psycho-physiological, methodological, managerial.

This article discusses the types of motivation of medical personnel to work in primary positions. The relationship of motivation and individually - typological characteristics of the personality of students. This relationship, many students and their employers often do not take into account when choosing a specialization after graduation. The information, working methods, types of manipulations, approaches to the prevention and treatment of patients, and the requirements that patients make to medical personnel are very fast changing. There fore, it is important not only to learn and prepare a specialist, but also to motivate you to learn throughout your life. An important requirement when applying for a job is the ability to quickly learn new information, skills and adapt as painlessly as possible to changing working and living conditions. If we consider the life of a person from the perspective of his development as a whole person, we must ask ourselves the question of what drives the actions of this person and what is their meaning. What motivates and motivates him to any action?

Why are these issues important and significant? The answer is simple: for a more productive, non-conflicting communication, it would be optimal to learn to recognize the motives of actions, the methods of teaching and accepting information by a person, taking into account his individually - typological characteristics of the personality. Motivation is a dynamic psychophysiological psycho-physiological process that controls the behavior of a person and determines his organization, orientation, stability and activity.

Since ancient times, the main probability of the motives of human behavior has been simple and true. People just 
tried to survive. With the formation of a more complex society, goals changed, motivation and society put forward new requirements for people who should have certain individual psycho-physiological characteristics. Behavior and actions of a person began to be considered not just as a set of biological motives with innate personality traits [1].

Abraham Maslow opened a new direction in psychology humanistic psychology, which questioned the idea that human behavior depends only on meeting basic needs (in particular, food and safety) in the fifties of the last century. From this moment begins a new stage in the search for incentives and motivations of a person to achieve goals. In 1960, Douglas Mac Gregor, a professor of management at the University of Massachusetts, successfully applied some ideas of A. Maslow's theory in business. But, the healthcare sector has always been seen as an unprofitable industry and has been funded by the state [2]. With the development of the economy and society as a whole, the medical industry is partly on the rails of self-financing and self-sufficiency. It would seem that material interest will become a determining factor in choosing a profession, working in a particular medical institution and personnel issues to be decided by themselves. But A. Maslow was right in this case too: such motivation is not enough for a person. The result that we observe in Ukraine both in medical educational institutions and medical institutions is a low motivation for mastering theoretical and practical skills and a lack of staff both in private and state medical institutions.

\section{THE AIM}

Based on previous studies, develop medical and psychological recommendations to increase the motivation for the work of nurses and medical assistants.

Tasks: 1 . Identify the types of motivation. 2. To identify priority types of motivation for nurses and medical assistants in choosing the profession of a medical worker. 3 . To determine the most effective types of motivation as a structural component of the model of the system of medical and psychological support for the process of adaptation of medical college students to work in primary positions. 4 . To develop structural logical scheme to increase the motivation of students to choose specialization and the fastest adaptation in practical activities.

\section{MATERIALS AND METHODS}

In psychology, the following types of motivation are distinguished: external motivation - not associated with any type of activity, but due to some external circumstances (receiving a certain award); internal motivation - related to the content of the activity, but not with external circumstances (receiving positive emotions); positive motivation - based on positive incentives (if I do it nice, then I do it nice too); negative motivation - based on negative incentives (if I do not create problems for people, then they also do not create problems for me); sustainable motivation - based on the natural needs of the person; unstable motivation - requires constant external support.
The studies were approved by the commission on ethics and bioethics of the Kharkov National Medical University and were carried out in accordance with the requirements prescribed in the Helsinki Declaration of the International Medical Association "Ethical Principles of Medical Research with the Participation of People as the Object of Study", the Law of Ukraine On Personal Data Protection.

\section{RESULTS AND DISCUSSION}

There are additional types of motivation: individual, group, cognitive. In addition, they distinguish individual motives that drive people's actions: motive of self-affirmation; identification motive; motive of power; procedural - substantive motives; motive of self-development; prosocial (socially significant) motives; accession motive $[2 ; 3 ; 4]$.

According to the general classification, all motives can be divided into tangible and intangible. It would seem simple enough: a high salary should ensure the high quality of the employee's work. However, such a moment comes in the robot when material methods become completely insufficient. You can recall the Abraham Maslow pyramid, which explains that after satisfying basic needs, we want to satisfy the needs of communication, communication, self-esteem, respect from others, recognition, success and high marks, career growth, self-expression, self-identification.

Of course, until the needs of a lower level are satisfied, the needs of a higher level, the needs of a higher level for a person simply will not matter. In the work of medical personnel of medical institutions of Ukraine, both public and private, material motivation plays a relative role. Because if we talk about material motivation, we will still return to the pyramid of A. Maslow. Therefore, in the article we paid more attention to the methods and methods of non-material motivation, which, from our point of view, are not used sufficiently or competently by managers to increase labor productivity and maintain a constant staff. For training and adaptation of a new employee, we use the additional cost of time (from 6 months to 1 year), labor and emotions. We tolerate inconvenience in the work associated with a low level of professionalism and the lack of adaptation of the employee to the fullest. Therefore, to create comfortable conditions and motivation for the quality work of an employee is one of the important tasks of the leader $[5 ; 6]$. Intangible motivation of staff is a powerful team management tool. There is a set of measures that will increase: employee loyalty; improve working conditions; maintain a healthy atmosphere; increase the corporate spirit of the team.

Methods for selecting non-material motivation of staff should take into account the mentality, psychotypes and emotional state of employees.

Intangible types of motivation include: 1) Personal public praise (show the value of the employee's work). 2) Competition: the best employee of the month, contests, quests. The result can be a super prize (a trip to a significant event for a person), a forum, a conference or a tourist trip... 3) Career ladder and future prospects. It is unlikely that high-quality, 


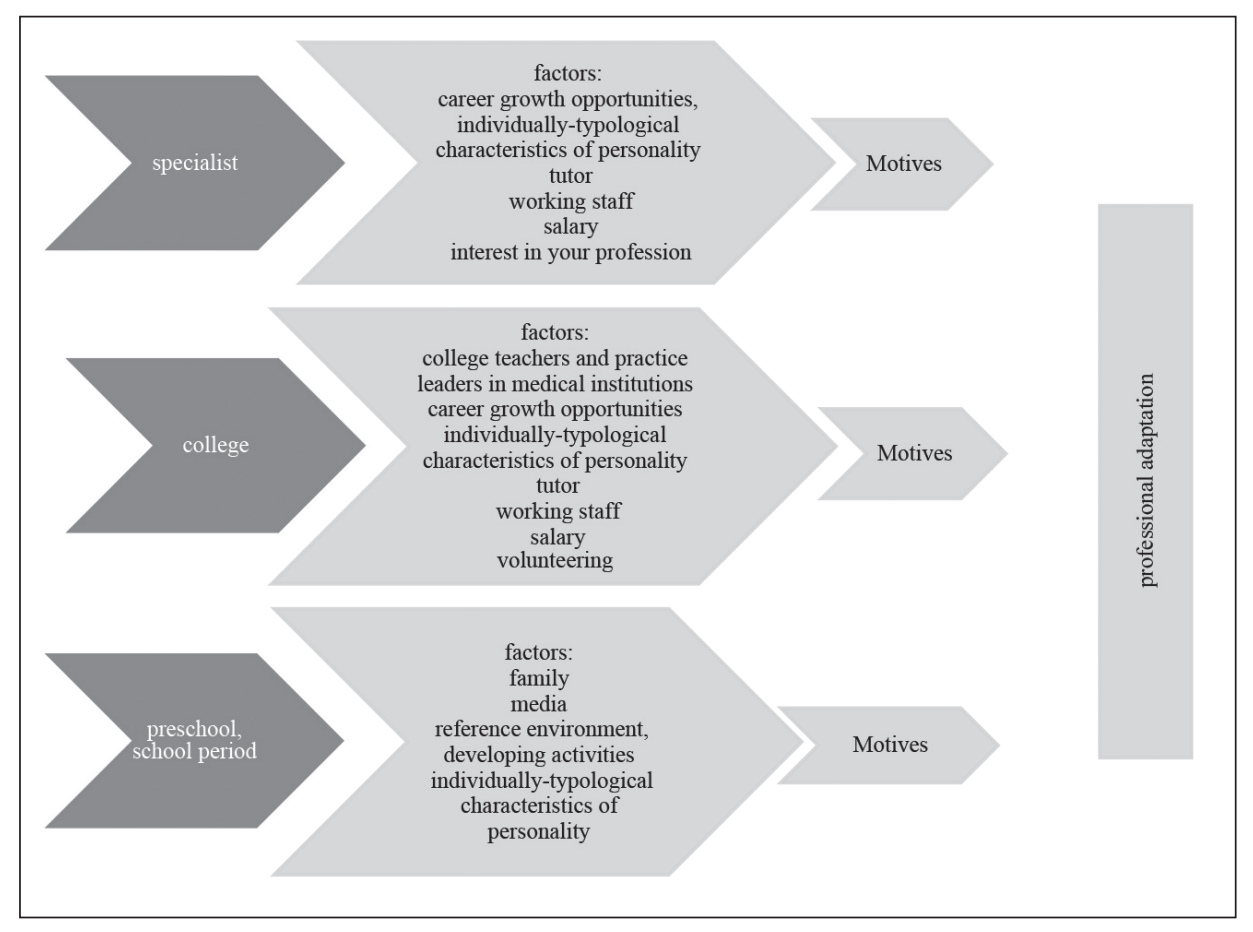

Fig. 1. Stages of the formation of personal adaptation to professional activities

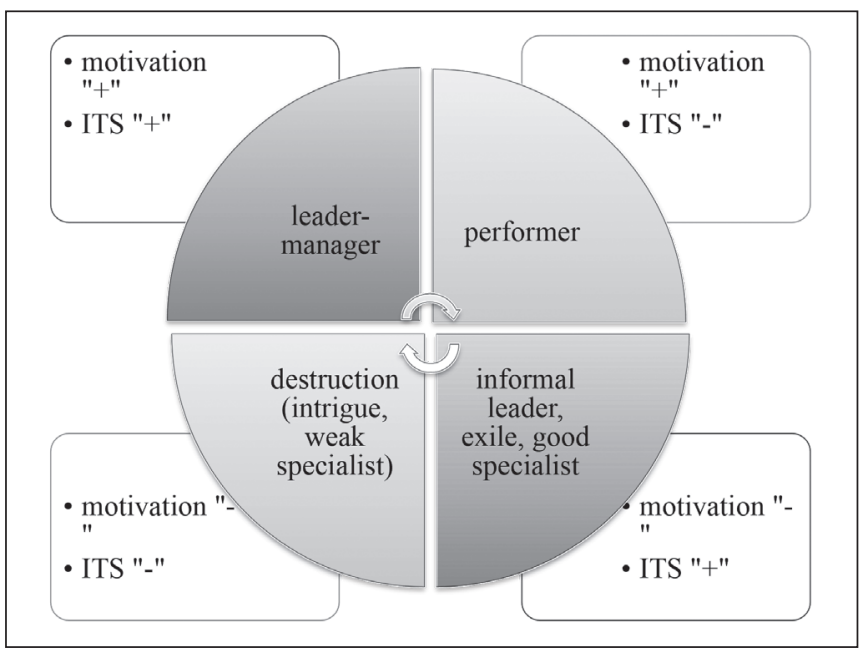

Fig. 2. The result of medical-psychological adaptation

promising and ambitious cadres will come to medicine without the possibility of career growth, an incentive for recognition and material interest. Such personalities can come, but only until the end of motivation, and then they will look for more interesting proposals in terms of motivation. 4) Training and professional development can contribute to the retention and cohesion of the team, and also makes it possible to attract promising employees. 5) Congratulations by individual, original ways to employees with significant dates. 6) Creation of the interior of the working area taking into account the peculiarities of the work of the personnel, their individual typological features, desires and national preferences. 7) Maintenance by own example and participation of a corporate spirit (corporate parties, tourist trips, sports competitions). 8) Using a flexible work schedule encourages a person to complete the task as quickly and efficiently as possible in order to get more free time. 9) Extra days off. 10) Freedom of action is the ability to evaluate the result, not the process of completing a task.

Sometimes a motivated specific employee needs non-material stimulation in the form of attention and gratitude or a competent leader with whom it is interesting and reliable to work or timely delegation of authority to the leader. The use of any kind of motivation without taking into account individually typological personality traits reduces the entire process of psychological support of an employee during the period of adaptation to work at low rates.

With increased sensitivity of the employee, motivation should be expressed in the form of support and warmth from the environment. Such employees are prone to neurosis and rapid burnout (Figure 1).

With increased spontaneity as an individual typological feature of the employee's personality, a tendency to respond quickly arises. With a well-designed step-by-step program of medical and psychological adaptation, we observe a quick, comfortable adaptation of the employee both in the team and in work. At the same time, such an employee may manifest conflicting character traits: rigidity, persistence turning into stubbornness, categorical in decision-making, impulsiveness in communication and a decrease in empathic qualities $[7 ; 8]$.

For employees with a high level of emotional labiality, who are very dependent on the reference group, the friendly atmosphere in the team, the ability to receive feedback, and incentive events (team-building games) can serve as non-material motivation.

Persons of this type are not only affected by the environment, but they themselves have a strong effect on the emotional state of others. This is a mixed response with erratic motivation. In a state of maladaptation, a hysterical type of behavior is possible. 
Employees with a high rigid type of response, which are characterized by stiffness of the nervous processes of both excitation and inhibition, are not relevant material type of motivation is support from the staff, the possibility of further training and feedback, informing about achievements and evaluating distinguished employees.

If we consider extroverts and introverts, then: extroverts - for them, a good motivation is the recognition of their achievements, which other people could see and evaluate. This may be a wall newspaper, praise before the whole team, a joint visit with the leader of a significant event. On the one hand, the sociability of such people is conducive to communication, but on the other hand, their communication can be superficial. Extroverts do not always know how to show empathic qualities, because the focus of their attention is often directed to a common group of people and they are waiting for reciprocal attention to themselves.

For introverts, motivation for work may be an interest in the work or study, internship; incentives in the form of time off or material incentive in any of its manifestations.

As a rule, each activity is always prompted by a complex, a combination of procedural - substantive (intrinsic - internal) and extrinsic (external) motives. Circumstances that exercise pressure and control (pressure from the doctor, patient, and patient's relatives), emphasize their incompetence, do not provide clear, adequate information regarding their progress in school and career, only weaken internal motivation. Figure 2 shows a diagram of the stages of the formation of personal adaptation to professional activity, taking into account different motivation at certain stages of personality formation.

In this article, we did not consider the effect of motivation on an employee depending on the degree of his professional maturity. Although, when choosing ways and methods of motivation, it is necessary to take into account the level of professional competence of the employee. Not material motivation is not effective if we do not take into account individually - typological characteristics of employees, age and their preferences.

\section{CONCLUSIONS}

After analyzing the above data, we can say that the combination of motivation or its absence with certain individual and typological characteristics of individuals leads to different results, which we displayed in our drawings. If the motivation is positive and ITF is consistent with the profession of a medical professional, then we have a chance to get a leader - a leader. If the student has a high enough motivation for mastering the profession, but the ITF does not quite correspond to the chosen profession, we can get a good performer. If ITFs correspond to mastering the profession of a medical specialist, but there is no motivation, we can get an informal leader, a rebellious, but competent specialist. However, it can also develop in a destructive way (to leave the profession). If there is no motivation and the ITF does not correspond to the profession of a medical worker, but the reference environment or circumstances independent of it lead such people to medicine, we get a destructive personality, an intriguer and a weak specialist.

An imbalance of individual - personality structures leads to the strengthening of individual character traits (accentuation), which contributes to maladaptation and professional burnout. The correct combination of material and non-material types of motivation, based on individual - typological characteristics of a person, allows achieving the most effective results in the process of adaptation and further work of medical personnel.

\section{SUGGESTIONS}

The result of this study is recommendations to parents, future specialists, teachers of educational institutions and heads of medical institutions.

Earlier studies of individual typological characteristics of a person, motivation, formation of leadership qualities, as well as ways and methods of their formation allow us to state the following: the sooner you begin to form internal motivation in a child, the less difficulties and higher the effectiveness of training, upbringing, education and adaptation both in society and in specialty.

Properly individually selected forms and the degree of combination of internal and external motives for a particular person facilitate the process of choosing a profession, adapting to it, as well as obtaining moral and material satisfaction.

The medical psychologist's accompaniment of the stages of personality formation and the creation of appropriate motivation during the formation of professional identification will help to avoid the occurrence of psychosomatic pathology, a change in the type of activity and a decrease in personality self-esteem.

Introduction to the staffing table for the selection and work with medical personnel in medical institutions of the rate of a medical psychologist will prevent unprofessional selection and placement of personnel. For a medical institution, this is an opportunity to retain a talented employee, to reduce the time, material and personal costs of selecting and training a new candidate.

\section{REFERENCES}

1. Pink D. Driyv. Dyvovyzhna Pravda pro te, shsho nas motyvuye [The Surpris Truth About What Motivates Us]. Kharkiv, 2016:208. (UA)

2. Sobchyk L.N. Upravliynnya personslomipsishodiahnostika: prakticheskoe rukovodstvo [Personnel management and psychodiagnostics: practical guide]. Moscow, 2010:186. (RU)

3. Novikova E.A., Ostrovskaya I.V. Adaptaziya sestrinskoho personala na rabochem meste [Adaptation of nursing staff in the workplace. The successes of modern science]. The successes of modern science. 2014;6:132-138. (RU)

4. Anzupova V.V., Hryshnyaeva 0.V., HryhorukV.V. et al. Samostiyna robota studentiv vyshshsykh navchalnykh zakladiv Ukrayiny yak odyn z etapiv yikh adaptaziyi do roboty v likuvalno-profilaktychnykh zakladakh [Independent work of students of higher educational establishments of Ukraine, as one of the stages of their further adaptation to work in health care establishments]. Clinical and experimental pathology. 2017;16(2):124-127. (UA) 
5. Hryshnyaeva 0.V. Liderstvo v medsestrynstvi yak skladova shvydkoyi adaptatsiyi do roboty v likuvalno-profilaktychnykh zakladakh [Leadership in nursing as a component of rapid adaptation to work in health care settings]. Medical psychology. 2018;13(3):42-46. (UA)

6. Dirksen D. Iskustvo obuchat: kak sdelat lyuboe obuchenie neskuchnym $i$ effektivnym [The art of teaching: how to make any learning fun and effective]. Moscow, 2015:276. (RU)

7. Voss K. Perehovory bez kompromisov. Vedi perehovory tak, slovno ot nikh zavisit tvoya zhyzn [Negotiations without compromise. Negotiate as if your life depends on them]. Moscow, 2017:320. (RU)

8. Sobchyk L.N. Psikhodiahnostika v meditsine [Psychodiagnostics in medicine]. Moscow, 2007:415. (RU)

9. Zelenin V.V. Mezhdu velichiem i travmoi: traktat o selektivnoy psishodiahnostike $v$ kouchinhe: monohrafiya [Between greatness and trauma: A Treatise on Selective Psychodiagnostics in Coaching]. Kyiv, 2015;1:272. (UA)

This article was performed within the framework of the initiative research of the Department of Psychotherapy of the Kharkiv Medical Academy of Postgraduate Education «States of Mental Disadaptation" (clinic, diagnostics, pathogenetic mechanisms, principles of rehabilitation therapy and medical and psychological correction). Budget financing, grants, etc. were not used.

\section{ORCID and contributorship:}

Olena V. Gryshnjaeva - 0000-0001-6704-8541 A,B,C,D,E,F

Oleksandr A. Melnychenko - 0000-0001-5021-9025 A,D,E,F

Galyna V. Yeryomenko - 0000-0001-5569-8918 ${ }^{A, F}$

Victoria V. Grigoruk - 0000-0002-8937-7802 C,D,F

Vita V. Antsupova - 0000-0002-7849-2602 ${ }^{C, D, F}$

Yana A. Vanina -0000-0003-3587-4886 ${ }^{B, F}$

\section{Conflict of interest:}

The Authors declare no conflict of interest.

\section{CORRESPONDING AUTHOR}

Olena V. Gryshnjaeva

Kharkiv National Medical University, Kharkiv, Ukraine tel: +380501017966

e-mail: elena1969lena1969@gmail.com

Received: 10.03 .2020

Accepted: 07.05 .2020 